\title{
Review of National Employment Policy of Ethiopia: Reference to Labor Proclamation 1156/2019
}

\author{
Zewdu Teshome \\ Federal Meles Zenawi Leadership Academy, Addis Ababa, Ethiopia
}

\author{
DOI: $10.7176 / \mathrm{PPAR} / 10-3-03$ \\ Publication date:March $31^{\text {st }} 2020$
}

\section{Introduction}

A policy is a definite course or method of action selected (by government, institution, group or individual) from among alternatives and in the light of given conditions to guide and, usually, to determine present and future decisions (Webster's dictionary). Public Policy is a statement by government on what it intends to do or not to do such as law, regulation, decision or order, or a combination of these that govern a particular issue areas or problem (Birkland, 2001:9). Public policy may refer to what government intends to do to achieve certain goals. This definition makes public policy look like a mere decision. That is to say that mere declaration of intentions, wishes, principles, or expression of desires cannot be called public policy. Public policy should mean actual resource allocation presented by projects and programs designed to respond to perceived public problems and challenges requiring government action for their solution. That is, it should mean hard patterns of resource allocation presented by projects and programs designed to respond to perceived public demands. This conception of public policy can be identified with a political scientist, James E. Anderson who defines policy as a relatively stable, purposive course of action followed by an actor or set of actors in dealing with a problem or a matter of concern (Anderson, 1997). This statement focuses on what is actually done instead of what is only proposed or intended, and it differentiates a policy from mere decision, which is essentially a choice among competing alternatives. Public policy, therefore, is that policy developed and implemented by government agency and officials, though non-state actors and factors may influence its process.

A country like Ethiopia with abundant labor force is, thus, required of to have a right employment policy in place in order to effectively use its growing labor force in a productive manner. In this regard the country is exerting efforts to make sure that new entrants to the labor force are equipped with the necessary knowledge, skill, and attitude that the economy needs. Micro and Small Enterprises have strategic relevance for employment creation, poverty reduction, rural-urban linkages, and for the growth of the private sector. A considerable number of permanent and temporary employment opportunities are being created as a result of the appropriate investment policy of the country attracting the private sector and also due to public investments especially in infrastructure, urban development, and housing construction.

The country's unemployment is a result of mismatch between rapidly growing labor force and the rate of growth of productive employment and income generation opportunities of the economy. Employment in the agricultural sector and the informal urban sector, which employ a large size of labor force in Ethiopia, is characterized by low earnings and significantly contributes to the problem of "working poor". Rapid population and labor force growth and limited employment generation capacity of the modern industrial and agricultural sectors of the economy both in urban and rural areas of the country create imbalance between labor demand and supply. Employment provides a link between economic growth and poverty reduction by allowing the poor to generate income; and this can be realized only when it is systematically guided through national policies and strategies. To alleviate the problems of unemployment and underemployment and thereby eradicate poverty, there is a need to adopt a national employment policy in order to address issues related to labor supply, labor demand, and labor market institutions in a coordinated and participatory manner.

The objective of this policy review project is, thus, to make a critical evaluation/review of the Ethiopian employment policy and strategies with respect to other countries experiences. The paper presents description of main policy issues, discussion of theoretical and empirical framework on the issue under investigation, the critique from the perspective of policy analyst, and future actions including recommendations.

\section{The Policy Description}

Ethiopia first established its National Employment Policy and Strategy (NEPS) in 2009. The objectives had three dimensions: objective of providing guidelines for streamlining productive employment and decent working conditions in the country and there by promote social welfare and equity through poverty reduction; objective of accelerating and sustaining economic growth and development through proper utilization of the country's labor force in a productive manner as the most important resource of the country; and objective of contributing towards reducing and avoiding political and civil unrest that would result from mass of unemployment by addressing both the supply and demand side of the labor market towards the creation of productive employment. The latest version 
of the NEPS was endorsed by the Council of Ministers in April 2016, which aimed at ensuring that full, productive, and freely chosen decent employment is promoted in the country. The Policy and Strategy is supposed to alleviate problems of unemployment, help eradicate poverty, and address labor and employment related issues in the country. The policy also plays critical role in facilitating effective employment environment for employees and employers. Besides, it gives particular attention to people with disabilities and women by adopting practical and supportive strategies that ensure equal participation in labor market and income generation activities. The preparation of NEPS was initiated by the Government of Ethiopia through the Ministry of Labor and Social Affairs. The preparation or development of this policy and strategy document has undergone a process of stakeholder/actors participation including the International Labor Organization (ILO), Ministry of Labor and Social Affairs, the private sector, and relevant regional bureaus. The policy has also some general principles by which its framework is being guided. These policy principles include:

- All citizens who are able to work have indiscriminate rights for employment opportunities.

- Compliance to labour standards is the basis for decent work.

- Social dialogue and work place cooperation are instrumental for labour productivity and competitiveness.

- Labour market information is fundamental for effective human resource development and employment. The policy prioritizes decent employment opportunities, improving labor market information and employment services, creating enabling environment that facilitates transition from informal to formal economy, maintaining industrial peace, and other cross-cutting issues for employment creation. As employment policy is wide and multi-sectoral in its nature, it requires an integrated implementation modality involving government and other stakeholders. Accordingly, a National Employment Council (NEC) will be established comprising the representatives of relevant public sectors at federal and regional level, Workers' and Employers' Associations, representatives from the informal sector and others as appropriate.

The Ethiopian government is committed to work in collaboration with other stakeholders towards creating and promoting decent employment opportunities. Social partners -employers and workers (and their associations) - can play a considerable role in settling conflicts and labor disputes that might arise between them through consultation, social dialogue and workplace cooperation which in effect can contribute to industrial peace and decent employment. Therefore, it is expected that employers, workers, and their respective associations become strong partners of the government and contribute their share to economic development, productivity growth, employment creation, and income generating activities. In view of this, social partners are expected to proactively participate towards successfully implementing the employment policy and in the monitoring and evaluation of activities to get feedbacks to rectify it.

\section{The Empirical Literature}

This section offers a brief discussion of other countries experiences in relation to national employment policy issues.

Nigeria National Employment Policy (NEP of Nigeria, 2017)

Nigeria developed and adopted its first National Employment Policy (NEP) in 2002. However, the policy was not comprehensive to consolidate into an integrated and coherent policy proposal that could effectively address the current labor market dynamics and realities in Nigeria. Consequently, the NEP was reviewed in view of the new national and global economic trends that influence work force development and employment generation.

The goal of the reviewed NEP is to create the enabling environment for productive and employment intensive growth in Nigeria.

The principles of NEP among others include:

- The NEP will be coordinated and implemented within the frameworks of national economic and social policy

- The Government policy on employment generation, in line with the economic reform programs, emphasizes the provision of a favorable environment for private investment and job creation.

- It is the private sector therefore, which should play the leading role of investing in the productive enterprise that provide increased employment and generate incomes.

- Individuals, groups, and the community at large, in line with decentralization and participatory development, also have important responsibility for employment creation.

- The Government should protect and assist vulnerable sections of the population such as women in the rural and urban informal sectors, the youth, elderly persons, those with disabilities, and unemployed through adequate safety net such as special compensatory and well-targeted programs.

- The NEP identifies programs and projects that create decent jobs in the key productive sectors of the economy and incentivizes the private sectors to invest in skill acquisition, employment and increased production.

Actors Involved In Policy Development, Formulation and Implementation

Several actors were involved in the process of the development of the country's NEP. First, the International Labor 
Organization (ILO), with an invitation from the Government of Nigeria, contributed to its efforts to the formulation of the 2002 NEP. After 14 years of existence, the NEP was reviewed due to series of development have taken place locally and globally in the labor market which were not anticipated when the policy was developed, which then made the policy outdated and ineffective in directing the national efforts toward full and productive employment. As a result, the Ministry of Labor and Employment of Nigeria sought and secured the active support of ILO to review the NEP. A two-man consultant committee also participated to conduct two diagnostic studies for the commencement of the policy revision process. Those actors such as social partners, Government Ministries, departments and agencies working in the field of employment creation, economic development skill acquisition, especially those assigned roles in the NEP, the private sectors and employer groups, youth, academics, as well as labor and trade unions contributed to their inputs in various consultations. Some more consultations were also held with various stakeholders and social partners for additional inputs to the first and second drafts of the policy document. Again all these stakeholders jointly participated to review and unanimously validated the policy document along with the implementation matrix at a workshop held in Abuja on $27^{\text {th }}$ October, 2016. After validation, the Federal Ministry of Labor and Employment of Nigeria (FMLE) consulted a technical committee to finalize the policy and align it with the policy direction of the present administration. The final draft of the reviewed policy, through the FMLE, approved by the Federal Executive Council on $19^{\text {th }}$ July, 2017.

Those actors who are actively involved and collaborated in the good implementation process of the NEP include all Ministries, Departments and Agencies (MDAs), private sectors, social partners, and the employers' organizations. The roles of these actors and stakeholders is detailed hereunder.

The Federal Government under the auspices of the FMLE shall oversee the overall implementation of the NEP in the country. The MDAs shall also play key roles in the implementation of the policy. Among others, they shall monitor and evaluate employment outcomes of government policies; implement programs; coordinate activities of private sectors in relation to employment creation; collect, maintain and disseminate labor market information, etc. State and Local Governments are actors and stakeholders in facilitating employment generation and in implementing the NEP. Private sectors are actors in creating decent and sustainable employment; invest in labor intensive sectors of the economy; etc. Employer's organizations and professional groups shall promote the NEP by enabling private sectors comply with the labor standards stipulated by the laws; promoting corporate governance and social dialogues at the work places; etc. the worker unions commit social dialogue to ensure industrial peace; promote decent work environment; promote strategies for increase in labor productivity; etc. International Development Organizations such as ILO, UNDP, African Development Bank (AfDB), United Nations Industrial Development Organizations (UNIDO), and WB are actors in the development of the NEP and their roles also complement Government's efforts in the implementation of the policy in the country. NGOs and Civil Society are also actors in realizing the fundamental objectives of the NEP in Nigeria.

\section{Performance Indicators}

The key achievement indicators for measuring the impact of the NEP implementation include:

1. The number of newly registered SMEs by Federal, State and Local Government Areas.

2. Increase in ease of business registration and streamlining of business regulations, rates and taxes

3. Appreciable reduction in the level of unemployment among graduates of higher institutions of learning, and technical colleges

4. Improved quality of technical and vocational education graduates

5. Increased supply of the required skill set in the labor market

6. Increase in wage employment in the private sector

7. Increase formalization of the informal sector

8. Reduction in youth unemployment across Nigeria

9. Increase employment and participation of women in the labour force

10. Increase wage employment and accommodation of qualified persons with disabilities in public and private sectors

11. Increase in the creation of green and environmentally friendly jobs

12. Establishment and maintenance of a reliable labour market information system Availability of an effective (contributory and non-contributory) social protection scheme for workers

13. Safe work environment for workers

14. Regulation and reduction of casualization of labour

15. Availability and stable electric power supply

16. Increased funding for the field operations and other activities of the FMLE essential for the coordination and effective implementation of the employment policy.

17. Financial access and inclusion for MSME with single digit lending rates

18. Harmonization of various taxes and end to multiple taxation across states

Lesson Learned from Nigeria

- The rate of economic growth in Nigeria in recent years has been quite encouraging. 
- Multiple programs and initiatives have been created and implemented by many agencies at the federal and state levels of government to address the problem of unemployment in the country

- A Reviewed NEP -a wide ranging and overarching policy document- which has benefited from inputs from multiplicity of stakeholders.

- Alignment of NEP with country's social and economic policies, and also with home grown Poverty Reduction Strategy called "National Economic Empowerment and Development Strategy" (NEEDS).

- It is crucial to create an environment that enables job creation by maintaining a stable macro-economy and reforming regulations and systems that hinder job creation to solve unemployment issues.

- It is essential to align the NEP with country's overall social and economic policies, as well as the international labor standards.

- Mismatch between the supply of skills by the Nigerian educational system and demand for such skills in the labor market.

- $\quad$ The deficit of employment opportunities

- The inability of the economy to create sufficient decent jobs has made inclusive growth and poverty reduction difficult in the country

- The rapid growth of the economy has failed to create the capacity for high labor absorption through gainful employment opportunities.

- $\quad$ Poor coordination, lack of continuity of programs have resulted in considerable duplication of efforts and waste.

- Economic growth in Nigeria has been less inclusive and jobless in character.

- Labor market deficiency in the fundamental elements of labor rights, entitlements and systems that measure and promote decent work.

- Deficient to incorporate issues of social protection, and social dialogue, which promotes labor productivity.

- Country's labor market embedded in formal and informal economic systems have rendered difficult implementation of social protection, wage harmonization, and job-rich growth.

Lessons Learned from APEC Economies (Source: APEC, 2018)

If an economy fails to address structural problems timely, the economic crisis takes place at any time. As a result, the economy can be faced with a sudden drop in growth potential and youth unemployment problem. To overcome the economic crisis and the high unemployment rate, Korea has tried economic and labor market structural reforms, economic growth-employment-income distribution by well-designed economic and industrial development policies, labor market policies, and employment-friendly welfare policies. Stable economic development, flexibility and security of labor market, and employment-friendly welfare policies are important to create more decent jobs for young job seekers. In this respect, consistency and rationality of macroeconomic policy, labor market structure and welfare reform are very important in solving the youth unemployment problem. Labor market policy, welfare policy, and employment service delivery system are very important in addressing the youth employment problem.

Until the 1980s, Japan had the lowest unemployment rate among the major industrialized economies under Japanese employment practices, and employment of young people was not a big problem. However, in 1991 after the collapse of the bubble economy in the long recession, the demand for labor was lowered, so the unemployment rate rose, and the problem of youth employment was highlighted. In 2003, the Japanese government launched a policy to solve the problem by reporting that young people's employment problems (especially freeters or the NEETs problem) caused a decline in the economy's competitiveness. The main policy contents were the smooth transition from school to work, the transition from irregular to full-time and the employment of young people in small and medium-sized enterprises. These policies have achieved some results, but they have limitations.

The implications of the study on youth employment in Japan are as follows. First, current employment practices that can be employed at the same time as graduation are useful for a good transition from school to work. Second, it is the strengthening of vocational education. About $30 \%$ of college graduates turnover within three years of their first job. It is necessary to lower the first turnover rate by making the first job choice more accurate. In order to do this, it is necessary to provide education not only to provide a lot of job information in the school curriculum but also to increase the ability to select a job that is more suitable for oneself. Third, it is the realization of equal pay for equal work. It is very important to create a society in which workers can be treated with their consent no matter what kind of work style they choose through these efforts of eliminating the irrational gap between regular and non-regular workers.

Regarding youth employment, Singaporean case in terms of the small economy with lots of foreign workers comparing to total number of Singapore citizens could be characterized as the best example of small but economically advanced economy in South-east Asia region. Ye (2013) pointed out three important points, leading to a low level of youth unemployment in Singapore: First, ability-driven education in terms of manpower supply; Second, centrally planned manpower from demand side has been attributed to playing a key role in ensuring 
alignment between economic goals, priority industries, and training of workforce; Third, social benefits tied to employment, based on impetus to get a job-whether good or not- is high, because employment is intimately linked to contributions to one's Central Provident Fund(CPF) account.

\section{Theoretical Framework}

Policy refers to a broad statement that reflects future goals and aspirations and provides guidelines for carrying out those goals. Hill (1993: p.47) defines 'policy' as 'the product of political influence, determining and setting limits to what the state does'. To be more specific, when a government takes a decision or chooses a course of action in order to solve a social problem and adopts a specific strategy for its planning and implementation, it is known as public policy (Anderson 1975). Policy scientists argue that public policy is best conceived in terms of a process (Jenkins, 1978, Rose, 1976; Anderson, 1978). This is because policy decisions are not 'something confined to one level of organization at the top, or at one stage at the outset, but rather something fluid and ever changing' (Gilliat, 1984:p.345).

\section{The Imperial Regime}

In the history of Ethiopia, the 1931 constitution was a landmark for the legislature to the present day. The constitution convened the first bicameral parliament and concisely defined the structure of the legislature to consist of two deliberative chambers. The chamber of Senate were to consist of members appointed by the emperor drawn from the nobility whereas the Chamber of Deputies were appointed by the nobility and local chiefs until such time as the people were considered ready to elect the members of chambers of deputies themselves (The 1931 Constitution, Article 31 \& 32). Likewise, in the 1955 revised Constitution the Senate were formed from elite groups such as the princes, high government officials and other local governments appointed by the Emperor.

Differing considerably from the 1931, members of the Chamber of Deputies were elected by the people of Ethiopia. In both cases, however, the ultimate power was still in the hands of the Emperor; and the power of approving and disapproving parliamentary legislations resided on the supremacy of the monarch (Tiruye, 2015). The parliament was neither meant to carry out the usual functions of an elected legislature, nor was it a source of public authority (ibid). Shiferaw in Mulugeta Abebe (2005) also commented that, there had never been any channel of communication between the public and those at the top of policymaking structures; and consulting the affected parties both before and after policy decisions was not in practice. In 1963 the first formal labour law (on collective labour relations) was established with the "Labour Relations Proclamation No. 210/1963".

This proclamation recognized the rights of associations of employers and workers, as well as a system of collective bargaining, and it set up machinery for the settlement of trade disputes - the Labour Relation Board. The 1963 Labour Proclamation favors more to the employers than the massive workers. The argument is that this labour proclamation is not determined by the demands and actions of the bulk of workers but rather by those elite groups at the apex of policymaking structures. During this era, even the most important legal documents declared the executive power and the supremacy of the emperor over the policy formulating and implementing institutions in the entire country. There had never been any channel of communication between the public (members of society affected by policies, such as workers) and those at the top of policymaking structures. Therefore, consulting the affected parties before and after policy decisions was unthinkable (Mulugeta, 2005). There was no channel of communication between policymakers and the citizenry (ibid). The situation in Ethiopia during this era clearly shows that the views and preferences of the majority of the population are hardly considered when public policies are made. Policies are often made by the operators of the emperor's elite group to promote their self and class interests.

\section{Derg Regime}

After the dawn fall of Haileselasse in 1974, the Derg suspended the 1955 constitution and dissolved the emperor parliament. However there had no any written constitution for thirteen years until 1987, it officially declared the establishment of Provisional Military Administrative Council (PMAC) in place of the Emperial government. Towards 1977, the Derg introduced a congress, consisted of all surviving members of the Derg, the central committee composed of 32 members elected by the former and 16 standing committee members elected by the congress from the members of the central committee; and promulgated legislation that guides the policymaking process in the country (Meheret, 1997).

Regarding the process of policymaking Shiferaw in Mulugeta (2005) stated that the legal department in the office of the Chairman of the Council of Ministers had to initiate laws; the draft laws were to be sent to the Legal Committee, whose members include the Ministry of Education, Ministry of Foreign Affairs, the Deputy Minister of Finance, and the Deputy Ministry of Mines and Energy, a representative from the National Planning Supreme Council, the Department Head of Legal Affairs in the Office of the Chairman of the Council of Ministers, and the Minister or Head of the Agency sponsoring the draft legislation would deliberate the spirit of the legislation, and send that to the PMAC via the Office of the Council of Ministers (CoM) for approval. Nevertheless he noted that there were exceptions to the established procedure, when draft laws were assigned to a group of experts particularly established to examine bills and asked to provide their opinion and recommendation; and in some other cases, 
legislation was referred to a joint Legal and Administrative Committee or to a joint Legal and Economic Committee, all of which are established by the Office of the Council of Ministers (ibid). After having studied and fused their insight, the draft legislation would be sent to the Provisional Administrative Council for final approval; and the proclamation was published in Negarit Gazeta by the name of PMAC (Tiruye, 2015).

In 1979, even though the same personality remained in the leadership positions, the virtual power of decision making over the years shifted from the PMAC to the Commission for Organizing the Working People of Ethiopia (COWPE) which letter transformed to Workers Party of Ethiopia (WPE) in 1984. According to Mulugeta, 2005 cited in Tiruye (2015), after the establishment of the party, the Derg claimed that the single most important actor in the socio-economic policymaking process was the party of the working people with its philosophy and ideology of Marxism and Leninism. Although much of the statutory declarations were often made in the name of Derg, since the end of the 1970, WPE, together with the principle of Marxism and Leninism assumed a virtual control over the entire socio economic policymaking process (ibid).

After promulgating the 1987 Constitution, the supreme organ of state power resides to the National

Shengo (National Assembly) which had 835 members. Candidates to the National Shengo had to be nominated by regional branches of the WPE, mass organizations, military units, and other associations recognized by law and balloting for seats in the National Shengo was required to be secret. Elected members served five-year terms, and the body met in regular session once each year (Tiruye, 2015). The responsibility of National Shengo included: amending the constitution; determining foreign, defense, and security policy; establishing the boundaries, status, and accountability of administrative regions; and approving economic plans (PDRE, 1987).

The other important organ in the policymaking practice was the Council of State. The Council of State had further authority to issue decrees in the pursuit of the duties stipulated by law or assigned by the National Shengo. Alemante, 1992 cited in Tiruye (2015) further noted that it exercised the national legislative role when the National Shengo was not in session. The 1987 constitution clearly stipulated that the party is the leading organ of the state as well as the society' (PDRE, 1987). Furthermore, in the wake of the establishment of PDRE, the newly emerging state organ, administrative and autonomous regions were integrated into the machinery of central planning, party and state institutions. The above study also noted that the party and the executive use the legislature to legitimize their action, but will keep the legislature distant from actual policymaking process. Moreover, chaired by the head of the state (who was also the Chairman of the PMAC) the Council of Ministers (CoM) was empowered to follow up the implementation of policies, despite parallel appointments of loyal personnel drawn from the military had circumscribed their leverage. There had, therefore, been very limited circles of elite groups, mainly involving the PMAC and the Council of Ministers (which was comprised of civilian technocrats) which had virtual claims on agenda setting and the policymaking process.

During the Dergue period (1974-91) as part of the socialist order of state and society, labour law was based on the public ownership of the means of production and was subject to central planning and central management. ${ }^{1}$ The 1963 Labour proclamation was repealed and replaced by a new Labour Proclamation No. 64/1975, and contained almost all provisions of a socialist labour law. This labour proclamation granted many rights to the workers.

\section{The EPRDF Regime}

Since the 1990's, Ethiopia has transformed from a nearly failed state as a result of various brutal dictatorships, to one that has made progress through introducing radical political and structural changes. A new Constitution was adopted in 1995, establishing a Federal Democratic Republic. The Constitution of the Federal Democratic Republic of Ethiopia has brought about fundamental constitutional and political changes and has fundamentally influenced the policymaking process in Ethiopia. Since then, Ethiopia has conducted four elections held within a legal framework institutionalizing pluralism and democracy. These changes have necessitated the formulation and implementation of economic and social policies that will give effect to the principles embodied in the new Constitution (Tiruye, 2015).

The structure of government and the principles of policymaking entrenched in the Constitution, aimed at redressing the imbalances created by the past. Accordingly, Ethiopia is structured along the lines of bicameral parliament consisting of a Federal Council and a House of Peoples' Representatives where both a federal government and a state shall have legislative, executive and judicial powers (FDRE Constitution, 1995). The legislative organs are constitutionally declared to be the highest political authority and the law making power is vested on the same. Being one of the most important tasks of the parliament, policymaking is the chief device of elected bodies used to represent the needs and wishes of citizens through the policymaking process (Tiruye, 2015).

Again with the change in regime in 1991, the 1975 Labor Proclamation was repealed and replaced by the 1993 Labor Proclamation. This proclamation was repealed and replaced by Proclamation No 377/2003. And this proclamation has been repealed by Proclamation No 1156/2019. Both the 2003 and the present one, have tried to strike the balance between both the interests of the workers and the employers. This indicates that the present

\footnotetext{
${ }^{1}$ https://www.ilo.org/ifpdial/information-resources/national-labour-law-profiles/WCMS_158894/lang--en/index.htm
} 
government seems to follow the philosophy of incrementalism in policy making, which is based on the paradigm that policy decisions consists of partial modification or additions to existing policies, as in the case that Labor Proclamation No. 42/1993 was repealed by Labor Proclamation 377/2003; and this in turn repealed by the current Labor Proclamation No. 1156/2019 with incremental changes from the previous ones.

\section{Policy Critique}

This section tries to present the critical reviews and critiques by taking the case of the Ethiopian labour proclamation No. 1156/2019, and by emphasizing on its strengths and weaknesses or shortcomings throughout the policy processes. The House of People's Representatives approved a Labour Proclamation No. 1156/2019 that will repeal Labour Proclamation No. 377/2003 together with its amendments. The Proclamation replaces a law that has been in place for the last 16 years. This has been a period where Ethiopia saw major shift in investment and business environment as well as the overall labor market.

The new Proclamation acknowledges the key role of a skilled and disciplined workforce to Ethiopia's industrialization efforts and improve its global competitiveness by expressly stating in its preamble the need to create a favorable environment for investment. Accordingly, some of the critiques, as identified by Africa Legal Network $(\mathrm{ALN})^{1}$ of the new proclamation in comparison with the former proclamation will be presented hereunder. Strengths

More obligations to Employers: The new Proclamation maintains the obligations of the employer under the existing law, such as providing work to the employee, paying wages, respecting the dignity of the employee etc. In addition, the new law obligates the employer to: a) deduct union dues from the employee's regular wage, and transfer the cash into the trade union's bank account, if so requested by the employee b) raise awareness of employees on work rules of the organization c) register information on workplace location and work-related data and transfer to the Ministry of Labour and Social Affairs ("MoLSA").

New Rules on Minimum Wage: the idea of introducing a minimum wage has been a topical issue for the Ethiopian government for quite some time. Previous administrations have commissioned studies on minimum wage, though none of these were able to see the light of day. Under the new Proclamation, the government has gone one step forward to establish a Wage Board comprising of representatives of government, employees and trade unions together with other stakeholders that will carry out studies for setting and periodically revising minimum wages.

Increased Minimum Working Age: the Proclamation raises the minimum working age from fourteen years of age to fifteen while maintaining the list of tasks and conditions permitted to young workers.

Added Employee Benefits: The new Proclamation extends existing maternity leave from 90 consecutive days to 120 consecutive days. The 30 working days are granted prior to the mother giving birth and 90 consecutive days subsequent to birth. Furthermore, the law introduces, for the first time, paternity leave of three consecutive days for male employees. This is less generous from the 5 working days paternity leave that is granted to civil servants under the Civil Service law.

Amendment to Annual Leave Entitlements: The new Proclamation increases employees' annual leave days from 14 working days on the first year of service to 16 working days. An additional one leave day will be granted for every two years of services as opposed to every year of services as it was currently provided.

Extended Probation Period: probation period is doubled from 45 consecutive days to 60 working days. A probation period gives an employer the opportunity to test suitability of the employee for the position. Both employees and employers will have the right to terminate contracts without notice and with no legal consequences prior to the expiry of the probation period. The new proclamation retains the existing rules that a probation period must be agreed between the parties and it must be done in writing. The law does not presume probation to exist in the absence of a written undertaking. At the completion of a probation period, if the employment is not terminated, then a contract of employment for an indefinite period is presumed to have been created.

Adjustment to Overtime Work and Payment: the new Proclamation retains the maximum working hours to 8 hours a day and 48 hours a week. Work done in excess of these hours is considered as an overtime work. Under the new law, maximum overtime work is capped at 4 hours per day and maximum of 12 hours per week. The maximum monthly and annual overtime hours of 20 and 100 hours respectively were removed. Depending on the time of work, the rate of payment for overtime work has also slightly increased from 1.5 multiplied by daily hourly rates to 1.75 multiplied by daily hourly rate. As the previous legislation, the new Proclamation does not offer any flexibility for parties to agree the extension of an overtime beyond the limit stipulated by law.

Vicarious Liability for Employers: under the existing labour law, employers will be liable for any unlawful acts prohibited by law. These unlawful acts are those including but not limited to, discrimination of employees based on ethnicity, sex, religion, political outlook, HIV/ AIDS or disability or any other grounds; terminating a contract of employment contrary to the law; compelling employees to execute any task which is hazardous to life; committing sexual harassment or sexual assault at workplace; and physically abusing anyone in a work place. The

\footnotetext{
${ }^{1}$ https://www.africalegalnetwork.com/ethiopias-new-labour-proclamation/
} 
new Proclamation holds the employer liable if these acts are committed by any of its management employees. The effect of commission of these acts by either the employer or the managerial employee is that it will expose the employer, depending on the nature of the act committed, to a fine of up-to 60,000 birr or if repeated more than three times, for closure of its organization.

Employee Liability: the Proclamation expands the list of unlawful acts by employees (which under existing law include endangering life and property of the employer, taking away properties, reporting to duty while intoxicated, refusing to observe safety and accident prevention and refusing to submit to medical examination with the exception of HIV/AIDS), to include the following acts: a) making use of falsified document or an attempt thereof: b) conducting meetings during working hours in disregard to the time assigned by the collective agreement or without obtaining the permission of the employer; c) commit sexual harassment or sexual violence at workplace; and d) physically abusing anyone in a work place. The implication of the above unlawful acts is that the employer will be able to terminate the contract of employment without prior notice to the employee within 30 days of knowing the existence of commission of such acts.

New Rules on Sexual Harassment and Sexual Violence: The Proclamation introduced a new regime to regulate workplace sexual harassment and sexual violence. Sexual harassment includes any act that is made to persuade or convince another through utterances, signs or any other manner, to submit for sexual favor without his/her consent. Sexual violence includes any sexual harassment accompanied by force or any attempt thereof. Accordingly, employees that have suffered sexual harassment or sexual violence will be entitled to terminate their contracts without notice, and will also be eligible for severance payment and compensation. The law provides a higher amount of compensation payment for employees who are forced to terminate their contract, without notice, for reasons of sexual harassment and sexual violence. Forced termination of contracts by employees for reasons that are unlawful acts of the employer will entitle the employee to one month compensation payment whereas sexual harassment and sexual violence victims will be granted three months of compensation payment.

Grounds for Termination of Contracts: the existing Labour Proclamation allows employers' ability to terminate contract of employments only to specific conditions provided by law. Any termination that is not in line with the labour law will be deemed as unlawful termination. An unlawful termination of a contract by an employer may have two consequences. a) It may either allow the employee to be reinstated to his/her previous position or b) it may entitle the employee severance and compensation payments. Under the new proclamation, the same approach is retained and grounds for termination of contracts (with notice and without notice) are exhaustively listed. However, there were some adjustments made to the maximum number of days that employees may be late or absent from work. Failure to adhere to these numbers of days will entitle the employer to a summary termination of employment contracts. Accordingly, the new law provides that reporting late to work eight times in six months period; and absence from work for a total of five days in six months' period while being warned in writing of such a problem will lead to termination of contracts without notice. Furthermore, employers will be able to terminate contracts of employment with prior notice, if there is a manifested loss of capacity or skills on the part of the employees. Employer must, however, prove this by creating a performance evaluation system.

Redundancy: Under the existing law, if an organization is compelled to reduce its work-force, the organization is permitted to prioritize and retain those employees that have the highest skills and level of productivity. In case where there are employees with equal skills and rates of productivity, the law provides for the order of reduction that should be made. Thus, employees that have the shortest length of service and those having fewer dependents will be reduced first while expectant mothers and mothers within 4 months of post-natal will be reduced last. The new Proclamation adds those employees with disability (regardless of how the disability was acquired) not be subject to reduction prior to others. Other than this slight amendment, the law maintains the strict rules and procedures that must be followed in order to reduce any workforce.

Administrative penalties: the Proclamation increases the administrative penalties to be imposed on employers violating the rules of the Labour Proclamation. Accordingly, the range for fines attributed to various violations under the Proclamation has increased from 300-1200 to 5,000-70,000. In practice, these administrative penalties were seldom enforced by the MoLSA.

Shortcomings

Revision of the labour law has gone through various drafts and discussions over the past years. Since the enactment of the previous law in 2003, the Ethiopian labour force has dramatically changed in the last 16 years, with new industries requiring new set of skills and a shift employer-employee relations. A large majority of the provision of the Proclamation 377/2003 were directly transplanted to the new law verbatim. Although the Proclamation attempts to address some practical challenges encountered due to gaps in legislative drafting, the new law does not introduce new conceptual framework or shift to create a more private sector/investment friendly legal system.

Compared to the length of time it took to revise the law and the changes that were seen on the ground, many of the revisions under the Proclamation are not fundamental in nature. The new law does no exhibit any shift in policy, for example, in terms of relaxing some of the more restrictive rules on the ability of the employer to terminate contracts. 
It does not offer contractual freedom to the parties and flexibility to allow an employer and employee to on agreed terms different from what is stipulated under the law. Unless it is included in a collective agreement, the law leaves little space for a worker and an employer to independently agree the terms of an employment.

The scope of the labour law is applicable to all employment relations and does not offer industry specific exceptions. With the exception of managerial employees and the diplomatic community, the Proclamation is applicable to all sectors across the board. This does not take into account industry specific labour needs and requirements and the different labour dynamics that should be subject to different regulatory considerations. For example, countries adopt different labour rules for industrial undertakings and for service sectors. Although manufacturing and industrialization is a key development vision for the country, this is not sufficiently reflected in the labor law.

\section{Conclusion and Future Action}

The Ethiopian National Employment conditions has gone through a number of changes and improvements over the past years. The amendments made with the country's employment policies and the subsequent labor proclamations are showing this fact. However, these changes did not go parallel with the country's demands and aspects of development; and there needs still improvements in the current labor law proclamation. The Ethiopian labor force has dramatically changed in the last 16 years since the enactment of the previous Proclamation $377 / 2003$. However, most of the provisions of this proclamation were directly uprooted to the new labor law word by word. Therefore, it requires further reviewing on the basis of the various labor dynamicity and increasing business and industrial development of the country.

Ethiopia needs to grow and develop fast in order to reduce and ultimately eliminate poverty. This requires the designing or revising of policies and programs that contribute to the development of a culture of work and respect for the dignity of labor which enhance labor productivity and industrial peace. The current Labor Proclamation should be revised with the goal of promoting work discipline, business efficiency and competitiveness. The implementation of Articles of the Labor Proclamation should further be investigated, and thereby amendments should be made accordingly. A large number of the provisions under the new Proclamation are not exhibiting shift in policy in terms of relaxing some of the more restrictive rules on the ability of the employer to terminate contracts. Therefore, those provisions in relation to termination of contract of employment by the employer should further be examined. The labor law should also leave sufficient place for contractual freedom to the parties and flexibility to allow an employer and employee to on agreed terms different from what is stipulated under the current labor law or in a collective agreement.

Now a days, manufacturing and industrialization is becoming vital development dreams for Ethiopia. However, the proclamation does not take into account industry specific labor needs and requirements, and the different labor dynamics. Thus, specific labor laws for industrial undertakings is imperative.

\section{References}

Adam A. (2018). An Overview of Approaches to the Study of Public Policy. Department of Public Administration, Faculty of Administration, Ahmadu Bello University, Zaria.

Anderson, Charles, W. (1978). "The Logic of Public Problems: Evaluation in Comparative Policy Research," in Ashford, Douglas, E. (ed.) Comparing Public Policies: New Concepts and Methods, Chapter 1, pp. 19-41, Beverly Hills/London: Sage Publications.

Anderson, James, E. (1975). Public Policy Making, London: Thomas Nelson and Sons Limited.

Anderson, J.E. (1997). Public Policy-Making: An Introduction 3rd ed. Boston: Houghton Miffilin Company.

APEC (2018). Best Practices of Youth Employment Policies in Selected Asia-Pacific Economic Cooperation, Economies APEC Human Resource Development Working Group.

Birkalnd, A. (2001). An introduction to the policy process: theories, concepts and models of public policymaking 3rd ed. M. E Sharpe, Inc. Armonk, New York.

FDRE (1993). Labour Proclamation no. 42/1993, A.A., Ethiopia.

FDRE (2004) Labour Proclamation no.377/2003, A.A., Ethiopia.

FDRE (2019) Labour Proclamation no.1156/2019, A.A., Ethiopia.

Federal Republic of Nigeria (2017). National Employment Policy, Nigeria.

Gilliat, Stephen (1984). "Public Policy Analysis and Conceptual Conservatism," Policy and Politics, Vol.12, No.4, pp. 345-367.

Hill, Michael. ed., (1993). The Policy Process: A Reader, London: Harvester Wheatsheaf.

International Labour Office (ILO). 2014. Global employment trends 2014 (Geneva).

International Labour Organization (ILO). (2003). National Labour Law Profile: Federal Republic of Ethiopia.

Jenkins, W. I. (1978). Policy Analysis: A Political and Organizational Perspective, Oxford: Martin Robertson.

Martha K. (2012). Employment Challenges in Ethiopia. Addis Ababa University, Ethiopia.

Mosca, G. (1939). The Ruling Class, (Translated by Hannah D. Kahn), New York: McGrow-Hill Book Company. 
Mulugeta Abebe, (2005). A Critical Assessment of Institutions, Roles and Leverage in Public policymaking: Ethiopia, 1974-2004. PhD. Dissertation, South Africa.

Obi, E.A, Nwachukwu, C.L. and Obiora, A.C. (2008). Public Policy Analysis and Decision Making. Onitsha: Bookpoint Educational Ltd.

Paul K., Bethuel K., Akinyinka A., Catherine M. (2018). ASC Working Paper 140. Kenya, Nairobi.

Rose, Richard (1976). The Dynamics of Public Policy, London: Sage Publications Ltd.

Tiruye Alemu (2015). Policymaking Practice and Challenges of House of Peoples Representatives (HoPRs). Ethiopian Civil Service University, Addis Ababa, Ethiopia. 